\title{
PENTINGNYA PENCANTUMAN LABEL PANGAN PADA PRODUK-PRODUK PANGAN/CAMILAN UNTUK PERLINDUNGAN KONSUMEN
}

\author{
Umi Supraptiningsih \\ (Jurusan Syari'ah STAIN pamekasan, alumni S2 Universitas \\ Narotama Surabaya dan peserta Program Doktor Ilmu Hukum Untag Surabaya)
}

\begin{abstract}
Abstrak : Pada kenyataannya walaupun seperangkat aturan baik yang mengatur tentang pelabelan, iklan serta Perlindungan Konsumen sudah ada tetapi tidak diikuti dengan itikat baik dari para pelaku usaha yaitu tetap dengan prinsip mencari keuntungan setinggi-tinggi dengan modal yang serendah-rendahnya tanpa memperhatikan asas kemanusiaan (kesehatan dan jiwa), maka tetap tidak ada perlindungan terhadap konsumen.
\end{abstract}

Kata Kunci :Label, pangan/camilan, perlindungan konsumen

\section{Pendahuluan}

Banyaknya produk pangan/camilan yang beredar di masyarakat tanpa mengindahkan ketentuan tentang pencantuman label tentunya akan meresahkan konsumen. Seperti produk pangan/camilan yang kadaluwarsa, pemakaian bahan pewarna/pengawet yang seharusnya tidak diperuntukkan untuk makanan sehingga dapat mengancam kesehatan bahkan kematian.

Masyarakat sebagai konsumen perlu mendapatkan informasi yang benar, jelas serta lengkap tentang produk-produk pangan yang mereka konsumsi. Selain itu perlindungan konsumen haruslah mendapat perhatian yang lebih terutama di masa sekarang ini, investasi asing telah menjadi bagian pembangunan ekonomi Indonesia yang akan menimbulkan persaingan perdagangan dan dapat membawa implikasi negatif bagi perlindungan konsumen. ${ }^{1}$

1 Erman Rajagukguk, Pentingnya Hukum Perlindungan Konsumen Dalam Era Perdagangan Bebas, Hukum Perlindungan Konsumen, (Bandung : Mandar Maju, 2002), hlm 2. 


\section{Umi Supraptiningsih}

Pemerintah bertanggung jawab atas pembinaan dan penyelenggaraan perlindungan konsumen (pasal 29 ayat (1) UU No. 8 Tahun 1999), dengan upaya-upaya :

1. Terciptanya iklim usaha dan tumbuhnya hubungan yang sehat antara pelaku usaha dan konsumen;

2. Berkembangnya lembaga perlindungan konsumen swadaya masyarakat;

3. Meningkatnya kwalitas sumberdaya manusia serta meningkatnya kegiatan penelitian dan pengembangan dibidang perlindungan konsumen (pasal 29 ayat (4) UU No. 8 Tahun 1999).

Berdasarkan pasal 8 angka (1) Undang-Undang No. 8 Tahun 1999 tentang Perlindungan Konsumen menyebutkan :

"bahwa pelaku usaha dilarang memproduksi dan/atau memperdagangkan barang dan/atau jasa yang : 1) tidak mencantumkan tanggal kadaluwarsa atau jangka waktu penggunaan/pemanfaatan yang paling baik atas barang tertentu. 2) tidak memasang label atau membuat penjelasan barang yang memuat nama barang, ukuran, berat/isi bersih atau netto, komposisi, aturan pakai, tanggal pembuatan, akibat sampingan, nama dan alamat pelaku usaha serta keterangan lain untuk penggunaan yang menurut ketentuan harus dipasang/dibuat".

Selanjutnya pada pasal 2 disebutkan "bahwa salah satu perlindungan konsumen berdasarkan asas kepastian hukum"2.

Salah satu bentuk perlindungan hukum terhadap konsumen yaitu adanya kewajiban bagi produsen untuk mencantumkan label. Sebagaimana diatur dalam Peraturan Pemerintah No. 69 Tahun 1999 tentang Label dan Iklan Pangan, yang menyebutkan bahwa Label pangan merupakan sarana dalam kegiatan perdagangan pangan yang

\footnotetext{
${ }^{2}$ Yang dimaksud dengan Asas kepastian hukum dalam penjelasannya dimaksudkan agar baik pelaku usaha maupun konsumen mentaati hukum dan memperoleh keadilan dalam penyelenggaraan perlindungan konsumen serta negara menjamin kepastian hukum tersebut.
} 


\section{Pentingnya Pencantuman Label Pangan Pada Produk- Produk Pangan/Camilan Untuk Perlindungan Konsumen}

memiliki arti penting, sehingga perlu diatur dan dikendalikan agar informasi mengenai pangan yang disampaikan kepada masyarakat adalah benar dan tidak menyesatkan.

Pengertian label sebagaimana terdapat pada pasal 1 ayat (3) PP No. 69 Tahun 1999 menyebutkan bahwa "label pangan selanjutnya disebut Label adalah setiap keterangan mengenai pangan yang berbentuk gambar, tulisan, kombinasi keduanya atau bentuk lain yang disertakan pada pangan, dimasukkan ke dalam, ditempelkan pada, atau merupakan bagian kemasan pangan".

Bagi pelaku usaha ${ }^{3}$ diwajibkan mematuhi ketentuan tentang label dalam mengembangkan usahanya tentunya untuk menjaga perlindungan konsumen serta adanya kepastian hukum.

Pasal 6 UU No. 8 Tahun 1999 menyebutkan hak-hak dari pelaku usaha, yaitu :

a. menerima pembayaran yang sesuai dengan kesepakatan mengenai kondisi dan nilai tukar barang dan/atau jasa yang diperdagangkan;

b. mendapat perlindungan hukum dari tindakan konsumen yang beritikat tidak baik;

c. melakukan pembelaan diri sepatutnya di dalam penyelesaian hukum sengketa konsumen;

d. rehabilitasi nama baik apabila terbukti secara hukum bahwa kerugian konsumen tidak diakibatkan oleh barang dan/atau jasa yang diperdagangkan.

Sebagai konsekwensi dari hak tersebut, maka kepada pelaku usaha dibebankan kewajiban-kewajiban sebagaimana yang telah diatur dalam pasal 7 UU No. 8 Tahun 1999, sebagai berikut :

a. beritikat baik dalam melakukan usahanya;

\footnotetext{
${ }^{3}$ Pelaku usaha Oleh Yusuf Shofie dalam Bukunya Pelaku Usaha, Konsumen, Dan Tindak Pidana Korporasi, Cet. Pertama, (Jakarta : Ghalia Indonesia, 2002), hlm. 15 diartikan setiap orang perseorangan atau badan usaha, baik yang berbentuk badan hukum maupun bukan badan hukum yang ... Melakukan kegiatan......menyelenggarakan kegiatan usaha dalam berbagai bidang ekonomi.
} 


\section{Umi Supraptiningsih}

b. memberikan informasi yang benar, jelas dan jujur mengenai kondisi dan jaminan barang dan/atau jasa serta memberi penjelasan penggunaan, perbaikan dan pemeliharaan;

c. memperlakukan atau melayani konsumen secara benar dan jujur serta tidak diskriminatif;

d. menjamin mutu barang dan/atau jasa yang diproduksi dan/atau diperdagangkan berdasarkan ketentuan standar mutu barang dan/atau jasa yang berlaku;

e. memberi kesempatan kepada konsumen untuk menguji dan/atau mencoba barang dan/atau jasa tertentu serta memberi jaminan dan/atau garansi atas barang yang dibuat dan/atau yang diperdagangkan;

f. memberi kompensasi, ganti rugi dan/atau penggantian atas kerugian akibat penggunaan, pemakaian dan pemanfaatan barang dan/atau jasa yang diperdagangkan;

g. memberi kompensasi, ganti rugi dan/atau penggantian apabila barang dan/atau jasa yang diterima atau dimanfaatkan tidak sesuai dengan perjanjian.

Pada kenyataannya di pasaran lokal banyak ditemukan produk-produk makanan/camilan yang dikemas dalam plastik, kotak, dan lain-lain yang dikonsumsi masyarakat, sebagian dikemas dengan label tanpa mencantumkan nomor ijin produksi dari pihak yang memberi ijin serta tanggal daluwarsa. Hal yang demikian oleh para pelaku usaha dianggap kurang atau bahkan tidak penting. Sehingga perlunya informasi yang benar, jelas serta lengkap dan bagi pelaku usaha dengan pencantuman label ini dapat memperoleh perlindungan dan kepastian hukum.

Pencantuman label yang jujur tidak hanya berkaitan dengan kesehatan saja tetapi perlindungan secara batiniah perlu didapatkan oleh masyarakat, utamanya bagi masyarakat muslim yang memerlukan legalitas label "halal".

Pada akhir-akhir ini banyak terjadi pergeseran trend makanan dari makanan tradisional ke makanan cepat saji dan olahan yang tentunya memiliki beberapa resiko yang harus kita cermati. ${ }^{4}$

\footnotetext{
${ }^{4}$ Resiko pertama terkait dengan masalah kesehatan. Penggunaan bahan-bahan kimia sebagai bahan tambahan makanan seperti pengawet, pewarna, penyedap, dan
} 


\section{Pentingnya Pencantuman Label Pangan Pada Produk- Produk Pangan/Camilan Untuk Perlindungan Konsumen}

Mayoritas masyarakat muslim akan menolak keras bilamana dihadapkan pada khamr, bangkai, darah atau daging babi karena tahu tentang keharamannya tetapi tidak pernah sadar bahwa pada era globalisasi makanan yang melanda seluruh dunia, bahan-bahan yang haram sudah menyusup dimana-mana dalam bentuk samarannya. Khamr misalnya bisa ada di bleck forest, puding, kue sus, dan sebagainya. Dan yang paling banyak menuntut kewaspadaan adalah babi karena dia bisa ada dimana saja dalam bentuk apa saja. ${ }^{5}$

Tidak hilang di benak kita tentang kasus-kasus Ajinomoto, Obat Diet Slim 10, Obat nyamuk Hit, beberapa makanan yang mengandung zat pengawet mayat (formalin) dan yang terbaru ada beberapa produk makanan yang mengandung transgenik (zat yang dapat menyebabkan alergi dan kematian) dan masih banyak lagi kasus-kasus yang merugikan konsumen (masyarakat). Menurut hasil laporan Badan Pengawas Obat dan Makanan (POM) Surabaya, pelanggaran obat dan makanan antara bulan Januari hingga Oktober 2003 ada delapan kasus yang dinyatakan P21 dan 62 kasus masih diajukan untuk penyidikan ${ }^{6}$.

Dari laporan tersebut sebanyak 62 kasus hanya satu yang merupakan pelanggaran makanan sedangkan 61 lainnya merupakan pelanggaran obat keras dan obat tidak terdaftar. Adapun jenis pelanggaran makanan yakni berupa makanan yang mengandung bahan tambahan pangan (BTP) seperti formalin, boraks dan rodhamin.

Seperti diketahui dalam kehidupan sehari-hari Bahan Tambahan Pangan (BTP) sudah digunakan secara umum oleh masyarakat termasuk dalam pembuatan pangan jajanan. Masih

sebagainya, diduga erat kaitannya dengan meningkatnya jumlah penderita kanker. Bahkan kanker saat ini telah melonjak rangkingnya sebagai pembunuh nomor tiga dibawah serangan jantung dan tekanan darah tinggi. Resiko yang kedua harus dihadapi oleh konsumen muslim yang punya komitmen terhadap halal-haram.

5 "Halal Haram di Tengah Arus Globalisasi Makanan", Readers, Edisi I, Volume 1, (Desember 2005), hlm. 68.

6 "Kasus terbanyak pelanggaran obat", Surya, (Surabaya : 28 Oktober 2003), hlm. 20 


\section{Umi Supraptiningsih}

banyak produsen pangan yang menggunakan bahan tambahan yang beracun atau berbahaya bagi kesehatan yang tidak boleh digunakan/dikunsumsi manusia. Bahan pengawet merupakan salah satu Bahan Tambahan Pangan (BTP) yang umumnya digunakan untuk mengawetkan pangan yang mempunyai sifat mudah rusak7, tetapi tidak jarang produsen mempergunakannya pada pangan yang relatif awet dengan tujuan untuk memperpanjang masa simpan atau memperbaiki tekstur. Sedangkan pengawet yang diperbolehkan seperti benzoat, propionate, nitrit, sorbat, dan sulfat, sedangkan yang dilarang untuk dikonsumsi karena berbahaya bagi kesehatan adalah boraks (bersifat antiseptik dan pembunuh kuman) dan formalin (sebagai bahan pengawet mayat dan organ tubuh) sebagaimana diatur dalam Peraturan Menteri Kesehatan RI No. 722/Menkes/Per/X/88.

Pewarnapun sering digunakan produsen untuk bermacammacam pangan seperti sirup, kue, agar-agar, tahu, dan lain-lain. Pewarna yang diijinkan seperti karamel, beta-karoten dan kurkumin, sedangkan berdasarkan Peraturan Menteri Kesehatan RI No. 355/Menkes/Per/VI/79 mengatur tentang pelarangannya seperti butter yellow, citrus red no. 2 dan rhodamin $\mathrm{B}^{8}$.

Berangkat dari uraian diatas dapatlah kita kaji dan diskusikan tentang efektifitas berlakunya PP No. 69 Tahun 1999 terhadap Perlindungan Konsumen berkenaan dengan pencantuman label terhadap produk pangan/camilan.

\section{A. Pencantuman Label sebagai Perlindungan Hukum dan Kepastian Hukum}

Perdagangan pangan/camilan yang jujur dan bertanggung jawab tidak semata-mata untuk melindungi kepentingan masyarakat yang mengkonsumsi pangan saja, namun diharapkan kepada setiap orang yang memproduksi pangan atau memasukkan pangan ke dalam wilayah Indonesia untuk diperdagangkan dapat memperoleh perlindungan dan jaminan kepastian hukum.

\footnotetext{
${ }^{7}$ Balai Besar POM, Bahan Tambahan Pangan (BTP), (Surabaya, 2003), hlm 70 71.

${ }^{8}$ Ibid, hlm $81-82$
} 


\section{Pentingnya Pencantuman Label Pangan Pada Produk- Produk Pangan/Camilan Untuk Perlindungan Konsumen}

Persaingan dalam perdagangan pangan diatur supaya pihak yang memproduksi pangan dan pengusaha iklan diwajibkan untuk membuat iklan secara benar dan tidak menyesatkan masyarakat, melalui pencantuman label dan iklan pangan yang harus memuat keterangan mengenai pangan dengan jujur.

Begitu pula masyarakat harus diberi sarana yang memadai untuk mendapatkan informasi yang benar dan tidak menyesatkan melalui label dan iklan pangan. Dengan demikian masyarakat dapat mengambil keputusan berdasarkan informasi yang akurat sehingga tercipta perdagangan yang jujur dan bertanggung jawab. Khusus menyangkut label atau iklan tentang pangan yang mencantumkan pernyataan bahwa pangan telah sesuai dengan persyaratan atau kepercayaan tertentu, maka orang yang membuat pernyataan tersebut bertanggung jawab terhadap kebenaran pernyataan dimaksud.

Berkenaan dengan pelanggaran dalam hukum pidana yang dilakukan oleh pengusaha dikenakan sanksi pidana sebagaimana ditetapkan dalam Undang-Undang tersebut dan sisi lain konsumen yang dirugikan tidak memiliki hak apapun atas pelanggaran yang dilakukan oleh pengusaha tersebut. ${ }^{9}$

Pemberian nama dan/atau tanda-tanda pada Barang menunjuk pada label dari barang yang bersangkutan. Bilamana hal tersebut bertentangan atau melanggar ketentuan, maka perbuatan tersebut masuk dalam tindak pidana ekonomi. ${ }^{10}$

Dalam Pasal 41 - 45 Peraturan Menteri Kesehatan No. 79 Tahun 1978 mengatur tentang pengedaran makanan tanpa label menyatakan dilarang dan dapat diancam dengan sanksi-sanksi sebagaimana diatur dalam Kitab Undang-Undang Hukum Pidana (KUHP) dan atau dikenakan tindakan Administratif berupa penarikan nomor daftar produk dan atau tindakan lain berdasarkan peraturan perundang-undangan yang berlaku.

9 Nurmadjito, Kesiapan Perangkat Peraturan Perundang-undangan tentang Perlindungan Konsumen dalam Menghadapi Era Perdagangan Bebas, Hukum Perlindungan Konsumen, (Bandung : Mandar Maju, 2002), hlm. 15.

${ }^{10}$ Az. Nasution, Hukum Perlindungan Konsumen, Suatu Pengantar, (Jakarta : Daya Widya, 1999), hlm. 70. 


\section{Umi Supraptiningsih}

Sanksi-sanksi atas pelanggaran kewajiban memasang label makanan (dalam kemasan) diatur lebih lanjut dalam Undang-Undang Nomor 23 Tahun 1992 tentang Kesehatan. Pasal 84 UU No. 23 Tahun 1992 tersebut menyebutkan bahwa "perbuatan mengedarkan makanan tanpa label dinyatakan sebagai tindak pidana pelanggaran dengan ancaman pidana kurungan maksimum 1 tahun dan atau denda maksimum Rp 15.000.000,00 (lima belas juta rupiah).

Sanksi administrasi yang diberikan berupa pencabutan ijin atau pembekuan ijin usaha, sedangkan ketentuan yang menyangkut perlindungan kepada konsumen bilamana terjadi pelanggaran atas kewajiban sanksi dijatuhkan kepada pengusaha sebagai produsen barang dan jasa tidak ada. Disisi lain konsumen yang dirugikan tidak memiliki hak apapun atas pelanggaran yang dilakukan oleh pengusaha yang dicabut atau dibekukan ijinnya. ${ }^{11}$

Putusan pengadilan yang menjatuhkan sanksi berupa tindakan administratif berupa larangan mengedarkan, penarikan nomor daftar produk, pencabutan ijin usaha dan sebagainya terhadap perilaku usaha yang menyimpang dan merugikan konsumen. Lemahnya putusan pengadilan tersebut yang tidak secara serta merta memberikan ganti kerugian kepada konsumen atau suatu penyelesaian tertentu bagi konsumen yang telah mengalami kerugian atau penderitaan

Bilamana konsumen ingin membeli suatu produk pangan kemasan baik produk dalam maupun luar negeri, hendaklah memperhatikan dengan teliti labelnya. Label merupakan sumber informasi yang ingin disampaikan produsen kepada konsumen terhadap suatu produk. Semakin lengkap informasi pada label akan semakin bagus bagi konsumen dalam memutuskan jadi atau tidaknya untuk membeli, sehingga masyarakat sebagai konsumen perlu mendapatkan informasi yang cukup dari produsen/pelaku usaha mengenai makanan yang beredar agar konsumen dengan tepat menentukan pilihan pangan/camilan yang aman baginya.

Bilamana terjadi sengketa antara konsumen dan

produsen/pelaku usaha, menurut YLKI (Yayasan Lembaga

${ }^{11}$ Nurmadjito, Kesiapan Perangkat....., hlm. 15 


\section{Pentingnya Pencantuman Label Pangan Pada Produk- Produk Pangan/Camilan Untuk Perlindungan Konsumen}

Konsumen Indonesia)12 : "posisi konsumen sebagai penguat dalam hubungan kontraktual yang berkualifikasi perbuatan melawan hukum sangatlah lemah. Hal ini terlihat jelas dari pasal 1365 Kitab Undang-Undang Hukum Perdata (KUH Perdata) yang mengharuskan pembuktian dengan unsur-unsur:

(1) adanya perbuatan melawan hukum,

(2) adanya kesalahan atau kelalaian produsen,

(3) adanya kerugian yang diderita konsumen,dan

(4) hubungan kausal antara perbuatan melawan hukum dan kerugian yang dideritanya.

Mengharuskannya konsumen untuk melakukan pembuktian atas kelalaian atau kesalahan produsen dalam proses produksi adalah hal yang sangat tidak adil, sebab yang mengetahui proses produksi justru produsen sendiri. Bila menerapkan doktrin product liability (tanggung jawab produk), maka konsumen tidak lagi dibebani untuk membuktikan kelalaian produsen melainkan produsenlah yang harus membuktikan ada tidaknya kesalahan atau kelalaian yang ia lakukan selama proses produksi.

Dalam doktrin liability, tergugat dianggap telah melakukan kesalahan (presumption of equality) kecuali produsen dapat membuktikan kalau dirinya tidak melakukan kelalaian atau kesalahan sebagaimana yang dituduhkan. Bila produsen tidak dapat membuktikan bahwa ia tidak bersalah atau tidak lalai, maka ia berkewajiban mengganti kerugian yang diderita konsumen setelah menkonsumsi produknya.

\section{Efektifitas Berlakunya PP No. 69 Tahun 1999 terhadap Perlindungan Konsumen}

Tentang pelabelan sebagian besar produsen memasang sendiri label produknya, hal ini untuk menunjukkan jati diri dari produsen sehingga konsumen mudah untuk mengenalinya. Label tersebut dibuat sendiri oleh produsen. Namun dalam pembuatan

\footnotetext{
${ }^{12}$ YLKI, "Siapa Raja, Konsumen atau Produsen?”, Kompas, ( Jakarta, 2000), hlm. 63
} $-64$ 


\section{Umi Supraptiningsih}

label produsen tidak memenuhi persyaratan yang seharusnya dipatuhi. Seperti syarat pencantuman tanggal, bulan dan tahun kadaluwarsa yang sering tidak diindahkan. Dalam pasal 21 ayat (2) UU No. 23 Tahun 1992 tentang Kesehatan menyebutkan bahwa "setiap makanan dan minuman yang dikemas wajib diberi tanda atau label. Pada label ini berisi :

a. Bahan yang dipakai,

b. Komposisi setiap bahan,

c. Tanggal, bulan dan tahun kadaluwarsa, dan

d. Ketentuan lainnya.

Sedangkan untuk pangan yang mengandung BTP (Bahan Tambahan Pangan) menurut Peraturan Menteri Kesehatan Republik Indonesia Nomor 722/Menkes/Per/IX/88 tentang Bahan Tambahan Pangan, pada labelnya harus dicantumkan nama golongan BTP seperti golongan antioksidan, pemanis buatan, pengawet, pewarna dan lain-lain. Begitu juga pada wadah BTP harus dicantumkan label yang memenuhi ketentuan ${ }^{13}$, yaitu harus mencantumkan :

a. Tulisan "Bahan Tambahan Pangan" atau "Food Additive""

b. Nama BTP khusus untuk pewarna dicantumkan pula nomor indeksnya,

c. Nama golongan BTP,

d. Nomor pendaftaran produsen,

e. Nomor pendaftara produk, untuk BTP yang harus didaftarkan.

Syarat-syarat label seperti yang tercantum dalam pasal 3 ayat (1) PP No. 69 Tahun 1999 menyebutkan bahwa label berisikan keterangan mengenai pangan yang bersangkutan. Selanjutnya pada ayat (2) menyebutkan bahwa keterangan tersebut sekurangkurangnya mencantumkan :

a. Nama produk;

b. Daftar bahan yang digunakan;

c. Berat bersih atau isi bersih;

d. Nama dan alamat pihak yang memproduksi atau memasukkan pangan ke dalam wilayah Indonesia;

${ }^{13}$ Balai Besar POM, Bahan Tambahan....., hlm. 83. 


\section{Pentingnya Pencantuman Label Pangan Pada Produk- Produk Pangan/Camilan Untuk Perlindungan Konsumen}

e. Tanggal, bulan dan tahun kadaluwarsa.

Pada kenyataannya bagi produk-produk makanan kecil untuk memenuhi persyaratan tersebut sangat sulit sehingga diperlukan pembinaan supaya produknya dapat memenuhi persyaratan keamanan, mutu, dan gizi pangan, yang tentunya pelaksanaannya harus dilaksanakan secara bertahap.

Setiap produsen boleh-boleh saja mengklaim produk pangan/camilan yang diproduksinya aman untuk dikonsumsi konsumen, begitu pula para pedagang/penjual berpendapat sama bahwa produk yang mereka jual aman untuk dikonsumsi, sangat bertolak belakang dengan pilihan pihak konsumen yang sebagian besar tidak memperhatikan segi keamanan suatu produk karena konsumen lebih memilih rasa enak, tetapi sudah merupakan kewajiban tiap pelaku usaha (produsen) untuk beritikad baik dalam melakukan kegiatan usahanya.

Pencantuman label tidak dibuat dan dipasang asal-asalan (sembarangan) saja. Memang suatu label mudah untuk dibuat tetapi tanggung jawab pelaku usaha tidak semudah itu. Suatu contoh kasus yang terjadi di Amerika, dimana sekitar 50 berondong jagung bermerk yang berlabel, mulai dari popcorn super buttery (asin) sampai sugery sweet (manis) sedang diperiksa kandungannya. Hal ini menyusul laporan penelitian yang dilakukan EPA's di Amerika mengatakan bahwa popcorn (berondong jagung) bisa mencemari lingkungan oleh karena beberapa bahan kimia yang dilepaskan ke udara ketika sekantung plastik popcorn dibuka. Bukan itu saja tetapi paparan asap dari mentega perasa dalam popcorn yang dimasak dengan microwave dikaitkan dengan penyakit paru-paru. ${ }^{14}$

Begitu pula hasil penelitian yang dilakukan mahasiswa Fakultas Hukum Universitas Madura (UNIRA) di Pamekasan Madura pada tahun 2003, bahwa produk pangan/camilan dimadura $100 \%$ berlabel namun label tersebut tidak memenuhi persyarakat sebagaimana yang diharapkan dan diatur dalam PP No. 69 tahun 1999. Mereka membuat label hanya untuk menunjukkan jati dirinya saja. Label yang dipasang tidak mencantumkan tanggal, bulan dan

14 “Popcorn Picu Penyakit Paru-paru", Jawa Pos, (Senin, 15 Maret 2004), hlm. 35. 


\section{Umi Supraptiningsih}

tahun daluwarsa, komposisi bahan dasar dari makanan/camilan tersebut.

Dari hasil data di Kantor Dinas Perindustrian dan Perdagangan Kabupaten Pamekasan, ternyata label-label pada makanan/camilan tidak memenuhi standar (SNI) baik dalam pembungkus maupun sistem labelisasi, hal ini disebabkan karena kurangnya kesadaran pengusaha terhadap pentingnya labelisasi produk selain itu adanya ketakutan pengusaha dikenakan persyaratan-persyaratan seperti pembayaran pajak, SIUP (Surat Ijin Usaha Perdagangan), TDI (Tanda Daftar Industri) dan ijin SP (Sertipikat Penyuluhan) dan Dinas Kesehatan.

B.

C. Penutup

Pada kenyataannya walaupun seperangkat aturan baik yang mengatur tentang pelabelan, iklan serta Perlindungan Konsumen sudah ada tetapi tidak diikuti dengan itikat baik dari para pelaku usaha yaitu tetap dengan prinsip mencari keuntungan setinggi-tinggi dengan modal yang serendah-rendahnya tanpa memperhatikan asas kemanusiaan (kesehatan dan jiwa), maka tetap tidak ada perlindungan terhadap konsumen.

Begitu pula perlunya penerapan aturan yang tegas dan memberikan rasa keadilan kepada konsumen yaitu dengan andilnya lembaga peradilan selama ini dalam memutuskan kasus-kasus yang merugikan konsumen dengan hanya menjatuhkan sanksi berupa penutupan perusahaan dan/atau pencabutan usaha tanpa diikuti pemberian ganti rugi kepada konsumen yang telah mengalami kerugian baik harta maupun fisik/tubuh.

D. Daftar Pustaka

Az. Nasution, Hukum Perlindungan Konsumen, Suatu Pengantar, Daya Widya, Jakarta, 1999,

Balai Besar POM, Bahan Tambahan Pangan (BTP), Surabaya, 2003, Erman Rajagukguk, Pentingnya Hukum Perlindungan Konsumen Dalam Era Perdagangan Bebas, Hukum Perlindungan Konsumen, Mandar Maju, Bandung, 2002

Nurmadjito, Kesiapan Perangkat Peraturan Perundang-undangan tentang Perlindungan 


\section{Pentingnya Pencantuman Label Pangan Pada Produk- Produk Pangan/Camilan Untuk Perlindungan Konsumen}

Konsumen dalam Menghadapi Era Perdagangan Bebas, Hukum Perlindungan Konsumen, Mandar Maju, Bandung, 2002,

Yusuf Shofie dalam Bukunya Pelaku Usaha, Konsumen, Dan Tindak Pidana Korporasi, Ghalia Indonesia, Cet. Pertama, Jakarta, 2002,

YLKI, Siapa Raja, Konsumen atau Produsen?, Kompas, Jakarta 2000, 